\title{
Research Article \\ EVALUATION OF BOTANICALS AND BIO-AGENTS AGAINST Rhizoctonia bataticola CAUSING DRY ROOT ROT OF CHICKPEA
}

PATIDAR JAGDISH KUMAR*, SINGH PRASHANT KUMAR, KASHYAP VIVEK, SINGH REETI AND PATIDAR SATISH

Department of Plant Pathology, College of Agriculture, Rajmata Vijayaraje Scindia Krishi Vishwa Vidyalaya, Gwalior, 474002, Madhya Pradesh, India *Corresponding Author: Email - jdsplantpathology@gmail.com

Received: April 26, 2018; Revised: May 07, 2018; Accepted: May 15, 2018; Published: May 30, 2018

\begin{abstract}
Nine botanicals and seven isolates of Trichoderma Spp. were evaluated by following poison food technique and dual culture technique against Rhizoctonia bataticola. Among the botanicals, maximum mycelium inhibition was recorded in Zingiber officinale rhizome (47.98\%) followed by Datura stramonium leaf (43.35 \%), Allium sativum clove (39.74 \%) and Eucalyptus Globus leaf ( $37.86 \%$ ). Out of the seven isolates of Trichoderma Spp. tested against Rhizoctonia bataticola, T-6 showed highest inhibition percentage (67.32\%) followed by T-7 (63.61\%), T-3 (59.72\%) and T-5 (57.50\%).
\end{abstract}

Keywords- Botanicals, Trichoderma, Rhizoctonia bataticola, mycelium growth, Inhibition percentage

Citation: Patidar Jagdish Kumar, et al., (2018) Evaluation of Botanicals and Bio-Agents Against Rhizoctonia bataticola Causing Dry Root Rot of Chickpea. International Journal of Microbiology Research, ISSN: 0975-5276 \& E-ISSN: 0975-9174, Volume 10, Issue 5, pp.-1186-1190.

Copyright: Copyright@2018 Patidar Jagdish Kumar, et al., This is an open-access article distributed under the terms of the Creative Commons Attribution License, which permits unrestricted use, distribution and reproduction in any medium, provided the original author and source are credited.

Academic Editor / Reviewer:

\section{Introduction}

Gram or Chickpea (Cicer arietinum L.), a member of family Fabaceae, is an ancient self-pollinated leguminous crop, grown since $7000 \mathrm{BC}$, in different areas of the world [1]. It is the world's second most important food legume next to common bean. About $90 \%$ of the global chickpea production contributed by major chickpea producing countries includes India (67.4\%), Australia (6.21\%), Pakistan (5.73\%), Turkey (3.86\%), Myanmar (3.74\%) and Iran (2.25\%) [2]. Chickpea is attacked by 172 pathogens ( 67 fungi, 22 viruses, 3 bacteria, 80 nematodes and mycoplasma) from all over the world [3]. Some of the serious diseases in order of their importance are wilt Fusarium oxysborum f. sp. ciceri) wet root rot (Rhizoctonia solani), dry root rot (Rhizoctonia, bataticola) Ascochyta blight (Ascocthya rabiei) and collar rot (Sclerotium rolfsii). Rhizoctonia bataticola (Taub.) Butler is a nectrotropic fungus caused dry root rot of chickpea which is emerging as a serious threat to the chickpea production worldwide [4]. Botanical extracts are biodegradable [5] and their use in crop protection is a practical sustainable alternative. It reduces environmental contamination and health hazards [6]. Botanical fungicides are unique because they can be produced easily by the farmers and small industries [7]. Different plant extracts also used separately or in combination to control some other fungi by the farmers. Very few studies have conducted using plant extracts and fungicides in the country to control $R$. bataticola causing dry root rot of chickpea.

\section{Materials and methods}

\section{In vitro evaluation of botanicals against $R$ hizoctonia bataticola}

Nine botanicals viz., Azadirachta indica, Azadirachta indica, Datura stramonium, Eucalyptus globus, Calotropis spp., Zingiber officinale, Allium sativum, Parthenium hysterophorus and Allium cepa were tested in vitro by poisoned food technique against Rhizoctonia bataticola. Healthy fresh plant parts i.e., leaves, bulbs, seeds or rhizomes were taken, washed thoroughly with fresh water and finally rinsed with sterilized distilled water.
Fifty gram of plant parts were cut into small pieces and minced with the help of a grinder by adding $50 \mathrm{ml}$ sterilized distilled water. Double-layered muslin cloth were used to filter botanical extracts in $150 \mathrm{ml}$ conical flasks and plugged with nonabsorbent cotton. These filtered extracts were autoclaved at $1.2 \mathrm{~kg} \mathrm{~cm}^{-2}$ pressure for 20 minutes. Autoclaved extract was individually added into previously sterilized Potato Dextrose Agar (PDA) plates @ 20 percent and mixed thoroughly at the time of pouring in the previously sterilized Petri plates. Five mm discs of 10 days old culture of $R$. bataticola were inoculated at the centre of Petri plates. Three replications were maintained for each botanical. The plate without botanicals extract served as control. The Petri plates were incubated at $27 \pm 2^{\circ} \mathrm{C}$ temperature till the complete coverage in control plate. The percent growth inhibition (PGI) of the pathogen was worked out by using formula given by [8].

Where,

$$
P G I=\frac{C T}{C} \times 100
$$

$$
\begin{aligned}
& P G I=\text { Percent growth inhibition } \\
& C=\text { Growth in control } \\
& T=\text { Growth in botanical }
\end{aligned}
$$

\section{In vitro evaluation of bio-agents against Rhizoctonia bataticola}

The antagonistic potential of the Trichoderma isolates against $R$. bataticola was evaluated by dual culture method on potato dextrose agar medium. Five $\mathrm{mm}$ discs of $R$. bataticola was cut with a sterile cork borer and placed near the periphery of PDA plate. Similarly, antagonistic fungi were placed on the other side i.e., at an angle of $180^{\circ}$. Plates with no antagonists placed served as control for the pathogen. The plates were incubated at $27 \pm 2^{\circ} \mathrm{C}$ for seven days. Each treatment was replicated thrice. Growth of Trichoderma Spp. and $R$. bataticola were measured after recording full growth of the $R$. bataticola in control plate. The percent inhibition of fungal plant pathogens was calculated using formula: 


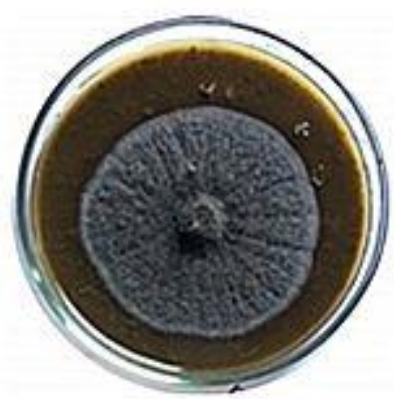

Azadirachta indica loat

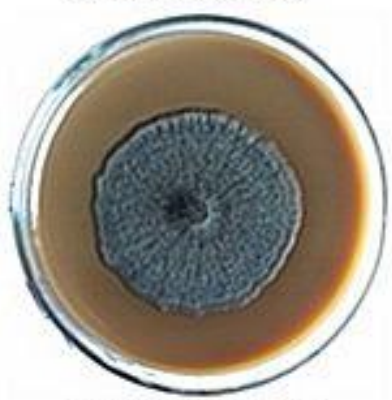

Eucalyptus Globus leaf

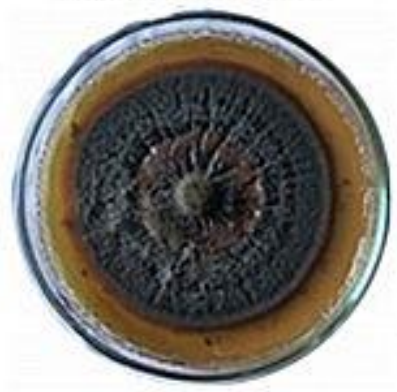

Parthondum hystorophonis loar

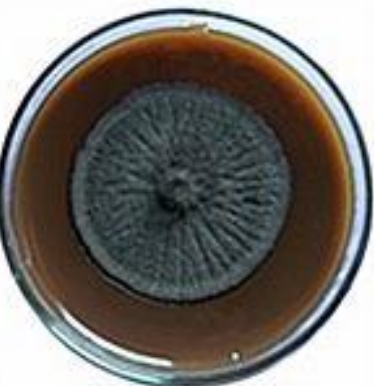

Azadiractira indiea seed

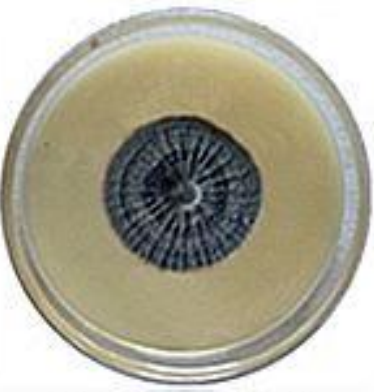

Zingiber officinato thizome

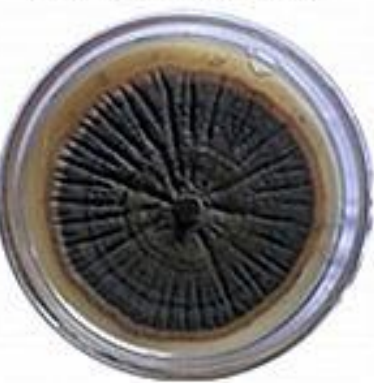

Allium copa bulb

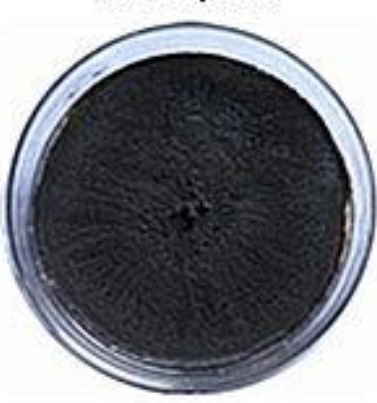

Control

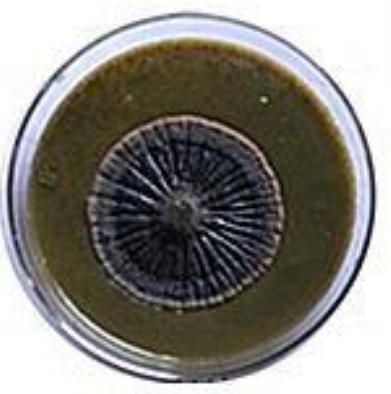

Dopura stramonicum Icat

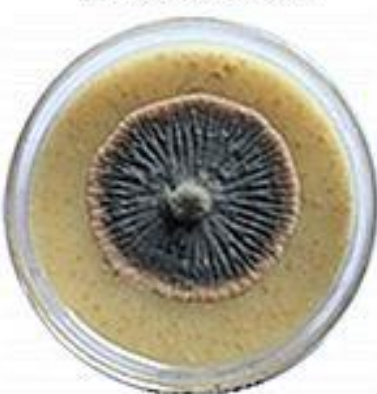

Allum sativum clove

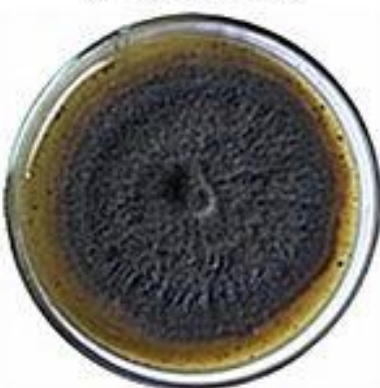

Colotropis

Plate-1 Effect of botanicals on the mycelium growth of Rhizoctonia bataticola

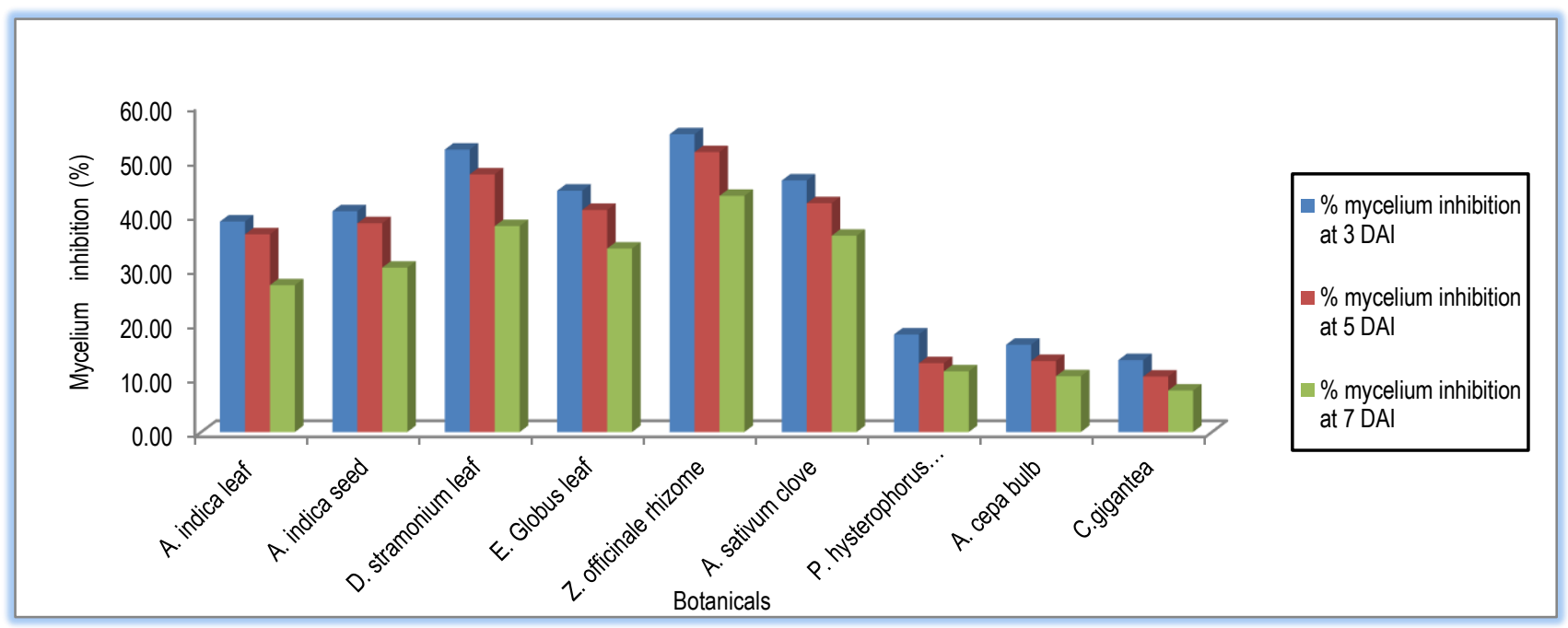

Fig-1 Percent mycelium inhibition of $R$. bataicola by different botanicals at different days after inoculation 
Patidar Jagdish Kumar, Singh Prashant Kumar, Kashyap Vivek, Singh Reeti and Patidar Satish
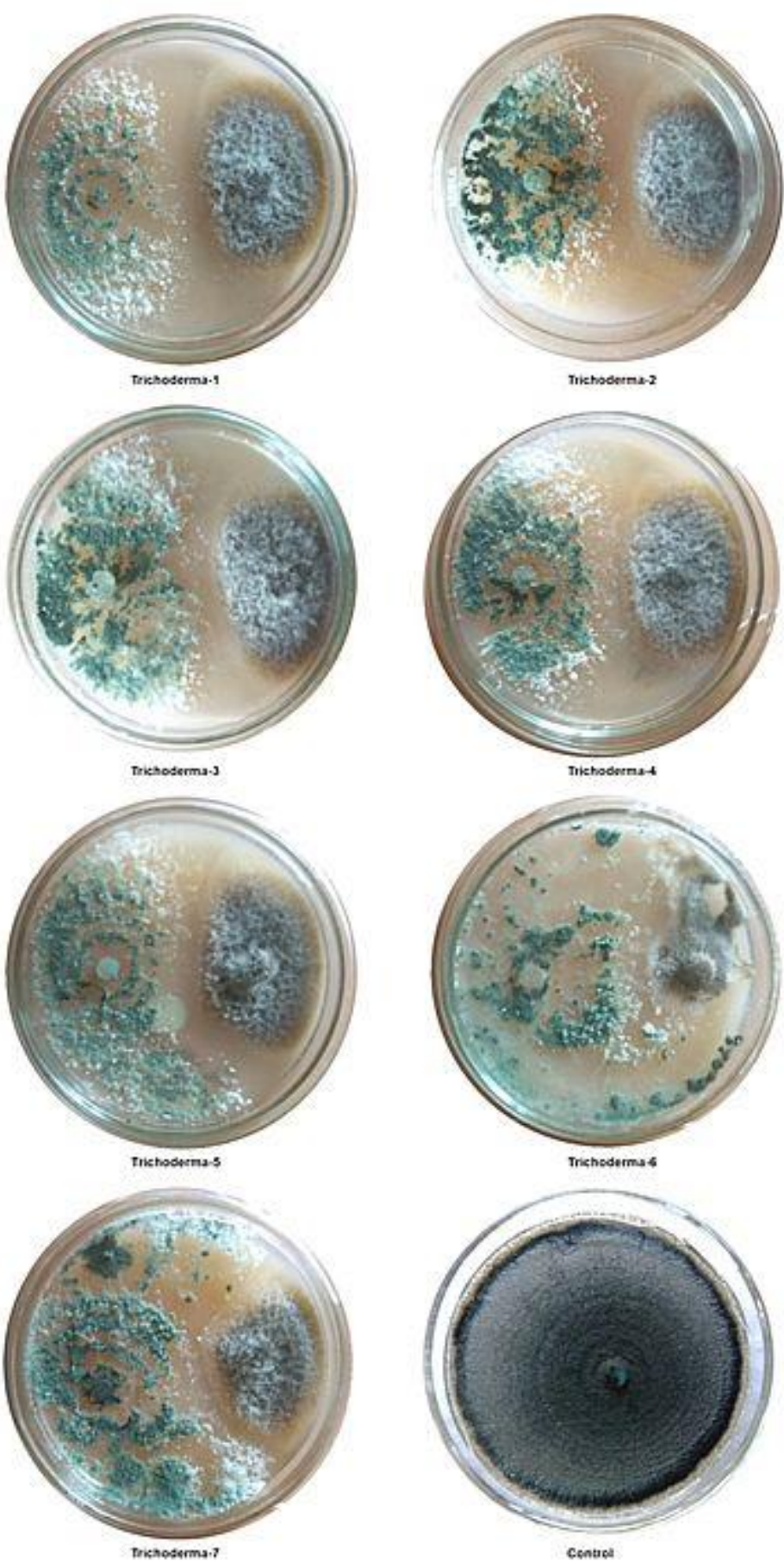

Plate-2 Interaction of Rhizoctonia bataticola with different strains of Trichoderma

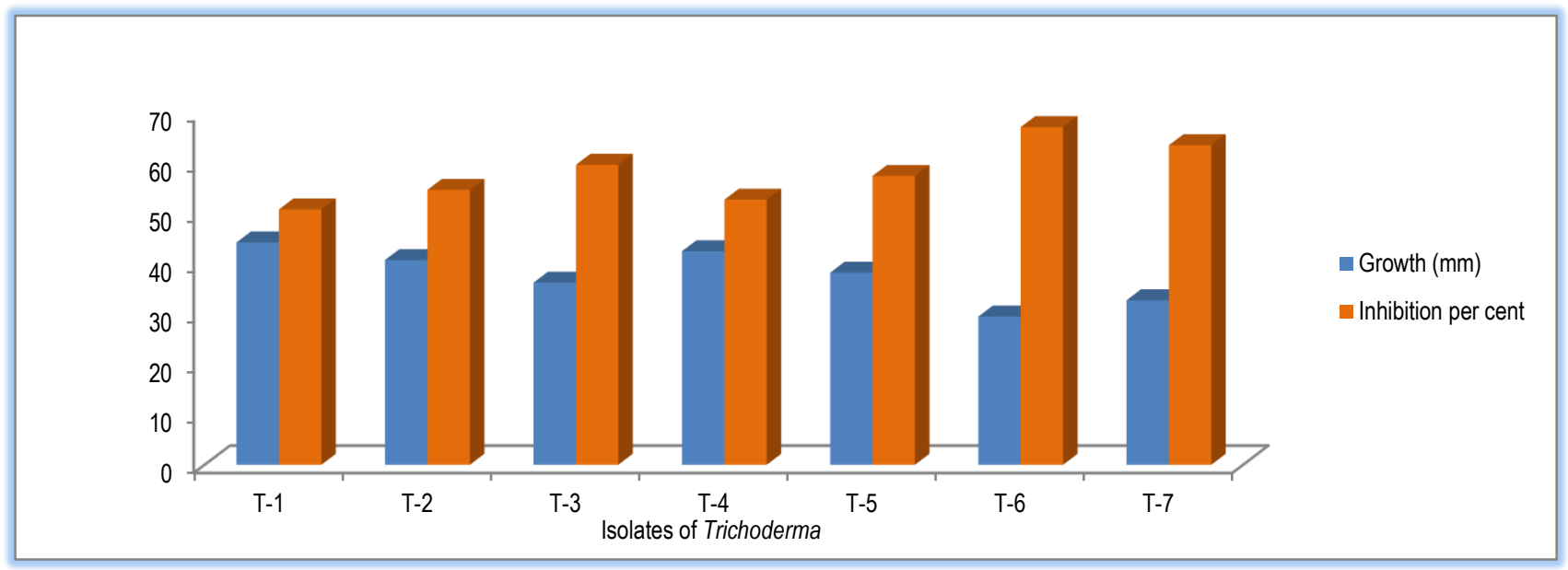

Fig-2 Mycelial growth and percent mycelium inhibition of $R$. bataicola by different isolates of Trichoderma 
Table-1 Efficacy of botanicals on mycelium growth of Rhizoctonia bataticola

\begin{tabular}{|c|c|c|c|c|c|c|c|c|}
\hline \multirow{3}{*}{ Botanicals } & \multicolumn{8}{|c|}{ Mycelium growth $(\mathrm{mm})$ and per cent mycelium inhibition at } \\
\hline & \multicolumn{2}{|c|}{ 3 DAl } & \multicolumn{2}{|c|}{$5 \mathrm{DAl}$} & \multicolumn{2}{|c|}{$7 \mathrm{DAl}$} & \multicolumn{2}{|c|}{ Overall mean } \\
\hline & Growth (mm) & Inhibition (\%) & Growth (mm) & Inhibition (\%) & $\begin{array}{l}\text { Growth } \\
(\mathrm{mm})\end{array}$ & Inhibition (\%) & $\begin{array}{l}\text { Growth } \\
(\mathrm{mm})\end{array}$ & Inhibition (\%) \\
\hline Azadirachta indica leaf & 16.25 & $38.68(38.39)^{*}$ & 39 & $36.33(37.06)^{*}$ & 62.25 & $26.98(31.28)^{*}$ & 39.17 & $32.08(34.50)^{\star}$ \\
\hline Azadirachta indica seed & 15.75 & $40.57(39.52)$ & 37.75 & $38.37(38.26)$ & 59.5 & $30.21(33.32)$ & 37.67 & $34.68(36.08)$ \\
\hline Datura stramonium leaf & 12.75 & $51.89(46.09)$ & 32.25 & $47.35(43.48)$ & 53 & $37.83(37.95)$ & 32.67 & $43.35(41.18)$ \\
\hline Eucalyptus Globus leaf & 14.75 & $44.34(41.74)$ & 36.25 & $40.82(39.70)$ & 56.5 & $33.72(35.49)$ & 35.83 & $37.86(37.97)$ \\
\hline Zingiber officinale rhizome & 12 & $54.72(47.71)$ & 29.75 & $51.43(45.82)$ & 48.25 & $43.40(41.20)$ & 30 & $47.98(43.84)$ \\
\hline Allium sativum clove & 14.25 & $46.23(42.82)$ & 35.5 & $42.04(40.42)$ & 54.5 & $36.07(36.90)$ & 34.75 & $39.74(39.07)$ \\
\hline Parthenium hysterophorus leaf & 21.75 & $17.92(24.92)$ & 53.5 & $12.65(20.71)$ & 75.75 & $11.14(19.48)$ & 50.33 & $12.72(20.84)$ \\
\hline Allium cepa bulb & 22.25 & $16.04(23.51)$ & 53.25 & $13.06(21.16)$ & 76.5 & $10.26(18.50)$ & 50.67 & $12.14(20.34)$ \\
\hline Calotropis & 23 & $13.21(21.21)$ & 55 & $10.20(18.52)$ & 78.75 & $7.62(15.82)$ & 52.25 & $9.39(17.80)$ \\
\hline Control & 26.5 & - & 61.25 & - & 85.25 & - & 57.67 & - \\
\hline $\mathrm{SEm} \pm$ & & 1.54 & & 1.07 & & 1.06 & & 0.67 \\
\hline C.D. at $5 \%$ & & 4.47 & & 3.1 & & 3.07 & & 1.96 \\
\hline
\end{tabular}

Where, I = Percent inhibition

$$
I=\frac{C T}{C} \times 100
$$

$\mathrm{C}=$ Growth of fungal plant pathogens in control $(\mathrm{mm})$.

$\mathrm{T}=$ Growth of fungal plant pathogens in dual culture plate $(\mathrm{mm})$.

\section{Results and discussion}

\section{Effect of botanicals on the growth $R$. bataticola}

Botanical extracts may be used as an alternative source for reducing incidence of soil-borne diseases because they have a rich source of bioactive substance $[9$, 10, 11]. Botanical extracts are eco-friendly, show structural diversity and complexity and infrequently comprise halogenated atoms [12]. In the present investigation, efficacy of nine different botanicals was evaluated on the growth of $R$. bataticola. Data presented in [Table-1], revealed that all the botanicals significantly inhibited the growth of $R$. bataticola. Significantly maximum mycelium inhibition was recorded in Zingiber officinale rhizome (47.98 \%) followed by Datura stramonium leaf (43.35\%), Allium sativum clove (39.74\%) and Eucalyptus globus leaf $(37.86 \%)$, however minimum mycelium inhibition was recorded in Calotropis spp. leaf $(9.39 \%)$ followed by Allium cepa bulb $(12.14 \%)$ and Parthenium hysterophorus leaf $(12.72 \%)$. At three days after inoculation, all the botanical significantly inhibited the mycelial growth of $R$. bataticola over control. Among the botanicals, maximum mycelium inhibition was recorded in Zingiber officinale rhizome $(54.73 \%)$ followed by Datura stramonium leaf (51.89\%), Allium sativum clove $(46.23 \%)$ and Eucalyptus globus leaf $(44.34 \%)$, however minimum mycelium inhibition was recorded in Calotropis spp. leaf (13.21\%) followed by Allium cepa bulb (16.46\%) and Parthenium hysterophorus leaf (17.92\%). At five days after inoculation, all tested botanicals significantly inhibit and reduced mycelial colony diameter over the control. Data presented in [Table-1] showed that significantly maximum mycelium growth inhibition was recorded in Zingiber officinale rhizome ( $51.43 \%$ ) followed by Datura stramonium leaf (47.35\%), Allium sativum clove (42.04\%) and Eucalyptus globus leaf ( $40.82 \%)$, whereas minimum mycelium inhibition was recorded in Calotropis spp. leaf (10.20\%) followed by Parthenium hysterophorus leaf (12.65\%). and Allium cepa bulb (13.06 \%). Data recorded on mycelium inhibition of $R$. bataticola at seven days after inoculation showed that all the screened botanicals significantly inhibited and reduced mycelial colony diameter over the control. Significantly maximum mycelium growth inhibition was recorded in Zingiber officinale rhizome (43.40\%) followed by Datura stramonium leaf ( $37.83 \%)$, Allium sativum clove ( $36.07 \%$ ) and Eucalyptus globus leaf $(33.72 \%)$, whereas minimum mycelium inhibition was recorded in Calotropis spp. leaf $(7.62 \%)$ followed by Allium cepa bulb $(10.26 \%)$ and Parthenium hysterophorus leaf $(11.14 \%)$ [Table-1], [Plate-1], [Fig-1]. Mandhare and Suryawanshi, (2009) [13] reported that Azadirachta indica extract inhibited the growth of the fungus by Allium sativum and Azadirachta indica found effective against $R$. bataticola, which was inhibited the mycelium growth by 77.77 and
$64.44 \%$ respectively. The other extracts were not effective. Kane, et al., (2002) [14] reported that crude extract of $A$. sativum, Eucalyptus globulens $L$. and Zingiber officinale $\mathrm{L}$. were effective in inhibiting the mycelial growth of the $R$. Solani to the extent of cent percent. Ammajamma, et al., (2009) [15] evaluated botanicals and reported that eupatorium was highly effective at 10 percent followed by garlic and neem leaf extract ( 50 \& 16.67\% respectively). Mallesh, et al., (2008) [16] observed the maximum inhibition of mycelial growth of $F$. solani and $R$. Solani with $10 \%$ garlic bulb and neem leaf extracts. Mandhare and Suryawanshi, (2008) [17] reported that Allium sativum (15\%) inhibited the growth of $R$. bataticola by $88.8 \%$. More and Parate, (2016) [18] reported that Azadirachta indica at 20 percent concentration inhibits 85.22 percent growth of Rhizoctonia bataticola.

Table-2 Mean of growth inhibition of Rhizoctonia bataticola by Trichoderma Strains

\begin{tabular}{|c|c|c|}
\hline \multirow[t]{2}{*}{ Trichoderma isolates } & \multicolumn{2}{|c|}{$\begin{array}{l}\text { Mycelium growth }(\mathrm{mm}) \text { and per cent mycelium } \\
\text { inhibition }\end{array}$} \\
\hline & Growth (mm) & Inhibition percent \\
\hline T-1 & 44.25 & $50.83(45.48)^{*}$ \\
\hline T-2 & 40.75 & 54.72 (47.71) \\
\hline T-3 & 36.25 & 59.72 (50.61) \\
\hline $\mathrm{T}-4$ & 42.50 & $52.78(46.59)$ \\
\hline T-5 & 38.25 & $57.50(49.32)$ \\
\hline T-6 & 29.50 & $67.22(55.09)$ \\
\hline T-7 & 32.75 & 63.61 (52.90) \\
\hline Control & 90.00 & - \\
\hline SEm \pm & & 0.61 \\
\hline C.D. at $5 \%$ & & 1.80 \\
\hline
\end{tabular}

\section{In vitro evaluation of Trichoderma spp. against $R$. bataticola in dual culture technique}

Besides chemical control, biological control is an effective, eco-friendly and alternative approach for any disease management practice. In the present experiment, seven isolates of Trichoderma were evaluated against $R$. bataticola by dual culture method. The results presented in [Table-2] reveal that all the isolates of Trichoderma suppressed the colony growth of $R$. bataticola. The suppression of the growth pathogen was maximum with T-6 $(67.32 \%)$ followed by T-7 $(63.61 \%)$, T-3 $(59.72 \%)$ and T-5 (57.50\%). The minimum inhibition was shown by T-1 $(45.56 \%)$ followed by T-4 (52.78 \%) and T-2 (54.72\%) [Table-2], [Plate-2], [Fig-2]. Bandyopadhyay, et al., (2003) [19] agreed with the finding and reported that strain of Trichoderma inhibited the growth of $R$. bataticola by 51.1 percent under in vitro conditions. 11 Trichoderma isolates evaluated by Paul, et al., (2008) [20] and reported that maximum mycelium inhibition of $R$. Solani was recorded in T. Harzianum (77 \%) under in vitro conditions. 
Kaushal, (2008) [21] reported that $T$. Harzianum was effective in inhibiting the mycelial growth of $R$. bataticola the causal organism of chickpea dry root rot. Maruti, et al., (2017) [22] reported that Trichoderma viride (TV-B) was found more effective and statistically significant over other bio-control agents in inhibiting the mycelial growth (77.20\%) of $R$. bataticola followed by Trichoderma virens (Tvn-B) $(75.76 \%)$ and rest of other treatments.

\section{Conclusion}

It is concluded that out of nine botanicals Zingiber officinale rhizome was found best which was recorded maximum mycelium inhibition of Rhizoctonia bataticola. Among isolates of Trichoderma Spp. T-6 was found best which was recorded maximum mycelium inhibition of Rhizoctonia bataticola.

Application of research: 1. Management of dry root rot of chickpea through botanical extract and bio-agents. 2. Management of plant disease without use of chemicals.

\section{Research Category: Plant Pathology}

\section{Abbreviations:}

$\mathrm{mm}$ : millimetre

${ }^{\circ}$ : Degree centigrade

Spp.: Species

viz: : Namely

$\%$ : Percent

Acknowledgement / Funding: Author are thankful to Rajmata Vijayaraje Scindia Krishi Vishwa Vidyalaya, Gwalior, 474002, Madhya Pradesh, India

\section{*Research Guide: Dr Reeti Singh}

University: Rajmata Vijayaraje Scindia Krishi Vishwa Vidyalaya, Gwalior, 474002, Madhya Pradesh, India

Research project name or number: Ph.D Thesis

\section{Author Contributions: All author equally contributed}

Author statement: All authors read, reviewed, agree and approved the final manuscript

\section{Conflict of Interest: None declared}

Ethical approval: This article does not contain any studies with human participants or animals performed by any of the authors.

\section{References}

[1] Tekeoglu M., Rajesh N.P. and Muehlbauer F.J. (2002) Theoratical Applied Genetics, 105, 847-854.

[2] Anonymous (2013-14) Ministry of Agriculture http://agricoop.nic.in

[3] Nene Y.L., Sheila V.K. and Sharma S.B. (1996) A World list of chickpea and pigeonpea pathogens. ICRISAT, $5^{\text {th }}$ edition. 1-27.

[4] Pande S. and Sharma M. (2010) In: $5^{\text {th }}$ International Food Legumes Research Conference (IFLRC V) \& 7th European Conference on Grain Legumes (AEP VII), Antalya, Turkey.

[5] Delvin J. F. and Zettel T. (1999) Ecoagriculture: Initiatives in Eastern and Southern Africa. Weaver Press, Harare

[6] Grange N. and Ahmed S. (1988) Handbook of Plants with Pest Control Properties. John Wiley and Sons, New York.

[7] Roy B., Amin R., Uddin M. N., Islam A. T. M. S., Islam M. J. and Halder B. C. (2005) Journal of Biological Sciences, 5(2), 201-204.

[8] Vincent J. M. (1947) Nature, 150 - 850.

[9] Chet I. and Henis Y. (1972) J. Gen. Microbol., 73, 483-486.

[10] Punja Z.K. (1985) Annu. Rev. Phytopathol., 23, 97-127.

[11] Wink M. (1993) In Methods in Plant Biochemistry, London: Academic
Press (Waterman, P.G., ed), 7, 197-240.

[12] Duke S.O., Dayan F.E., Romagni J.G., Rimando A.M. (2000) Weed Research, 40(1), 99-111.

[13] Mandhare V.K. and Suryawanshi A. V. (2009) J. Pl. Dis. Sci., 4(1), 128-129.

[14] Kane P.V., Kshirsagar C.R., Jadhav A.C. and Pawar N.B. (2002) J. Maharastra Agric. Univ., 27(1),101-102.

[15] Ammajamma R., Hegde Y.R.., Lingaraju S., Sreedevi S.C. and Hegde Laxminarayana (2009) Biomed., 4(1),28-32.

[16] Mallesh S.B., Narendrappa T. and Satish D. (2008) International J. of PI. Sci., 3(1): 82-86.

[17] Mandhare V.K. and Suryawanshi A.V. (2008) J. Food Legu., 21(2),122-124.

[18] More P.S. and Parate R.L. (2016) Int. J. Pl. Protec., 9(2), 469-473.

[19] Bandyopadhyay S., Sharma N.D. and Dutta, S. (2003) Ann. PI. Protec. Sci., 11, 163-165.

[20] Paul Y.S., Devi M. and Kapoor A.S. (2008) J. Mycol. PI. Pathol., 38 (3), 571-576.

[21] Kaushal R.P. (2008) J. Food Legume, 21 (3), 178-181.

[22] Maruti, Savitha A. S., Gururaj S. and Amaresh Y. S. (2017) Int. J. Pure App. Biosci., 5 (6), 1341-1347. 